\title{
Population regulation of blue crabs Callinectes sapidus in the northern Gulf of Mexico: postlarval supply
}

\author{
Steven G. Morgan*, Richard K. Zimmer-Faust**, Kenneth L. Heck Jr, Loren D. Coen***
}

Marine Environmental Sciences Consortium, PO Box 369-370, Dauphin Island, Alabama 36528, USA

\begin{abstract}
Larval supply and early postsettlement mortality are crucial to the maintenance of most marine populations. Larval supply may be especially important in regulating populations of blue crabs Callinectes sapidus because many larvae could be lost during long migrations between estuaries and offshore waters. We examined the relative contributions of differential transport and habitat preferences of megalopae (postlarvae) to 5 potential nursery habitats in Mobile Bay and Mississippi Sound, Alabama, USA. Settlement in each habitat was determined daily during summer and fall for 2 yr and was related to sea surface temperature, wind stress, tides, current velocity and the lunar and tidal amplitude cycles. In 1990, most megalopae settled when winds blew megalopae onshore and tidal amplitudes were minimal. In 1991, onshore winds were light and infrequent, and megalopae settled even more densely during minimum amplitude tides. Semidaily collections of megalopae at dusk and dawn revealed that most megalopae recruit to estuaries during nocturnal flood tides, which only occur during summer and fall in this diumal tidal regime. Thus, onshore winds facilitated transport of megalopae into estuaries episodically, but megalopae recruited regularly and abundantly during nocturnal minimum amplitude flood tides even when onshore winds were light or absent. Most megalopae were collected in the lower bay although some megalopae settled at the head of the estuary $50 \mathrm{~km}$ away from the baymouth. Megalopae required about $2 \mathrm{~d}$ to travel this distance as they became increasingly competent to settle from the plankton. Physiological tolerances may explain why most larvae settled in high salinity waters, but differences in current regimes may best explain differences in settlement among sites in the lower bay. Several types of substrate were transplanted from nursery habitats to a sandy area at the baymouth to determine whether megalopae prefer to settle in seagrass beds, marshes or unvegetated substrate once they arrive at a site. Megalopae strongly preferred to settle on vegetation, but it remains unclear whether or not they discriminate among plant types. Thus, passive delivery and habitat preferences of megalopae both may determine the initial distributions of juvenile blue crabs.
\end{abstract}

KEY WORDS: Larval settlement - Larval transport - Habitat preferences - Nursery areas - Estuaries

\section{INTRODUCTION}

Most marine animals develop as larvae in the plankton before returning to adult habitats. Larval mortality is generally assumed to be great due to high fecundities

Present addresses:

-Marine Sciences Research Center, State University of New York, Stony Brook, New York 11794-5000, USA.

E-mail: smorgan@ccmail.sunysb.edu

- Department of Biological Sciences, Marine Science Program, and Belle W. Baruch Institute for Marine Biology and Coastal Research, University of South Carolina, Columbia, South Carolina 29208, USA

-.Marine Resources and Research Institute, PO Box 12559, Charleston, South Carolina 29422, USA of adults, minute sizes of larvae and highly variable recruitment (Thorson 1950, Rumrill 1990). However, it has been argued that larval mortality may be overestimated because larvae appear to be better adapted to a planktonic existence than was previously thought (see Morgan 1995 for review). For example, it is widely believed that survival primarily depends on the passive return of weakly swimming larvae to appropriate settlement sites. However, it is becoming increasingly apparent that larvae of many species regulate the direction and distance that they travel by migrating between prevailing stratified currents (Boehlert \& Mundy 1988, Epifanio 1988, McConaugha 1988) and that they actively select suitable settlement sites (e.g. Johnson 1989, Young 1989, Mokady et al. 1991). 
Mortality of sessile and sedentary animals may be estimated much more reliably once larvae settle. Nevertheless, the uncertainty of larval mortality rates has generated considerable debate concerning the relative contributions of presettlement and postsettlement mortality in regulating population abundances in marine communities. The importance of both sources of mortality was recognized early in the century, postsettlement mortality was emphasized in the 1960 s and a more balanced view returned in the mid 1980 s (Underwood \& Fairweather 1989, Young 1990). It now appears that larval supply may be more important in regulating populations when settlement is low, and postsettlement mortality may be more important when larvae settle densely (Connell 1985, Forrester 1990. Jones 1990, Sutherland 1990, Menge 1991).

The purpose of this study was to determine whether or not this emerging paradigm applies to the population dynamics of blue crabs Callinectes sapidus in the Gulf of Mexico, USA. Ovigerous C. sapidus migrate to the mouths of estuaries and nearshore coastal waters where they release larvae (Provenzano et al. 1983, McClintock et al. 1993) that are transported as much as $100 \mathrm{~km}$ offshore (Smyth 1980, Truesdale \& Andryszak 1983, Epifanio et al. 1989) in near-surface waters (A. E. Matthews \& S. G. Morgan unpubl.). Approximately 31 to $49 \mathrm{~d}$ and 6 or 7 larval stages later they metamorphose into megalopae (Costlow \& Bookhout 1959 ) and mostly return onshore in wind driven surface waters (Johnson 1985, McConaugha 1988, Olmi 1995, Matthews \& Morgan unpubl.) or tidally forced internal waves (Shanks 1988). Once inshore, wind forcing (Johnson 1985) or subtidal transport (Goodrich et al. 1989, Little \& Epifanio 1991) may carry megalopae into the estuary. Megalopae then are transported by nocturnal flood tides to shallow water habitats (Epifanio et al. 1984, De Vries et al. 1994, Olmi 1994). The megalopa stage lasts approximately 6 to $20 \mathrm{~d}$ (Costlow \& Bookhout 1959), so that megalopae may not be competent to settle upon reaching suitable habitats (Lipcius et al. 1990, Metcalf \& Lipcius 1992, Wolcott \& De Vries 1994). Most megalopae settle in the lower estuary, but they can reach the heads of smaller estuaries (King 1971, Williams 1971, Perry 1975, Mense \& Wenner 1989).

Juveniles of many estuarine species develop in vegetated areas (Thayer \& Stuart 1974, Turner 1977 , Nixon 1980, Boesch \& Turner 1984), and as many as $95 \%$ of Callinectes sapidus less than $25 \mathrm{~mm}$ may occur there (Zimmerman \& Minello 1984, Orth \& van Montfrans 1987, Williams et al. 1990). However, different types of vegetated habitats may not be of equal value to the survival of blue crabs. Young juveniles appear to be much more abundant in seagrass beds than in adjacent marshes along both the Gulf. and Atlantic coasts of the USA (Orth \& van Montfrans 1987, Thomas et al. 1990) Juvenile crabs use marshes more on the Gulf coast, where prevailing onshore winds and low tidal amplitudes combine to inundate marshes from summer through early fall (Mense \& Wenner 1989, Thomas et al. 1990),

Different abundances of juvenile Callinectes sapidus in seagrass beds and marshes may be explained by differential transport of megalopae (Olmi et al. 1990), habitat preferences of megalopae (Orth \& van Montfrans 1987, Luckenbach \& Orth 1992), emigration and immigration of juveniles (Orth \& van Montfrans 1987. Mense \& Wenner 1989, Olmi et al. 1990) or postsettlement mortality (Wilson et al. 1987). We examined postlarval supply and postsettlement mortality at 5 sites along the coast of Alabama to determine which of these 2 factors most likely controls population abundances of blue crabs. In so doing, the relative contributions of various wetland habitats in maintaining blue crab populations were evaluated. Here we report the availability of postlarvae among habitats and compare our results with those of similar studies that have been conducied in estuaries on the Atlantic coast. The relative contributions of postlarval supply and postsettlement mortality in regulating population abundances of blue crabs are discussed in a companion paper (Heck et al. unpubl.).

This study was designed to provide insight into the mechanisms regulating the supply of megalopae to various habitats in Mobile Bay and Mississippi Sound. Settlement at the entrance to Mobile Bay was surveyed daily for 5 to 6 mo during 2 consecutive years and was correlated with environmental variables to determine whether winds, tides, moonlight or daylight influences the timing of recruitment to the bay. Settlement at 4 vegetated sites throughout the bay also was studied to determine whether physiological stress or current flow likely affects settlement. Megalopae penetrate over $90 \mathrm{~km}$ in large estuaries (van Montfrans et al. 1995) and should settle abundantly at the head of Mobile Bay, which is only $50 \mathrm{~km}$ from the baymouth. However, physiological tolerances (see Costlow \& Bookhout 1959) may limit settlement to the lower estuary. If currents deliver more megalopae to some sites than others (e.g. Connell 1985, Gaines et al. 1985, Eckman 1987), then settlement should be greatest where flow velocities are high. If megalopae are passively deposited (e.g. Butman 1989, Armonies \& Hellwig-Armonies 1992) in quiet vegetated backwaters, then settlement should be greatest where flow velocities are low. Finally, seagrasses and marsh grasses were transplanted to a sandy site at the entrance to Mobile Bay to determine whether or not megalopae discriminate among habitats. If so, megalopae should settle more abundantly on vegetated than unvegetated habitats 
and they should be most abundant on seagrasses, where juveniles most commonly occur (Orth \& van Montfrans 1987, Thomas et al. 1990). Alternatively, thigmotactic megalopae may be most abundant on marsh grasses because they provide the most surface area for settlement.

The lesser blue crab Callinectes similis occurs in coastal waters and the mouths of estuaries in the Gulf of Mexico, and therefore it co-occurs with C. sapidus in lower estuaries (Williams 1984). Postlarvae of both species recruited to lower Mobile Bay, and the timing, magnitude and distribution of settlement by $C$. similis also are reported.

\section{MATERIALS AND METHODS}

Study sites. In the northern Gulf of Mexico, blue crab megalopae invade shallow estuarine embayments through inlets in barrier islands. The entrance to Mobile Bay is approximately $5 \mathrm{~km}$ wide and $4 \mathrm{~m}$ deep except for a $12 \mathrm{~m}$ deep dredged ship channel (Fig. 1). The mean depth of Mobile Bay is $3 \mathrm{~m}$ and the length is $50 \mathrm{~km}$. The Alabama and Tombigbee rivers discharge $1850 \mathrm{~m}^{3} \mathrm{~s}^{-1}$ of water into Mobile Bay making it the fourth largest river system in the USA (Morisawa 1968). Low discharge (usually less than $500 \mathrm{~m}^{3} \mathrm{~s}^{-1}$ ) generally occurs during summer and fall (Schroeder \& Lysinger 1979) when most blue crab megalopae recruit to Mobile Bay. Approximately $85 \%$ of water in Mobile Bay is exchanged with the Gulf of Mexico through
Main Pass and the remainder is exchanged with Mississippi Sound (Schroeder 1978). Mississippi Sound is $130 \mathrm{~km}$ long, $15 \mathrm{~km}$ wide and about $3 \mathrm{~m}$ deep at mean low water. The mouth of Mobile Bay is stratified, the rest of the bay is partially mixed and the sound is predominantly well mixed (Eleuterius 1978, Lysinger 1982, Schroeder \& Wiseman 1986, Schell et al. unpubl.). Small amplitude (mean amplitude of $43 \mathrm{~cm}$ ) diurnal tides are dominated by the declinational cycle of the moon and maximum amplitude tropic tides do not always coincide with new and full moons. Tropic tides peak during the afternoon in summer when tidal currents at the baymouth attain $1 \mathrm{~m} \mathrm{~s}^{-1}$. Minimum amplitude equatorial tides occur when the moon crosses the equator 2 wk later and semidiurnal tides occur for 1 or $2 \mathrm{~d}$.

Approximately 3000 acres (1215 ha) of submerged aquatic vegetation and 5000 acres (2025 ha) of marshes along the coast of Alabama (Stout \& Lelong 1981) provide abundant habitat for juvenile blue crabs. We selected 4 different habitats in Mobile Bay and Mississippi Sound that might serve as nursery areas for blue crabs, and 1 additional site at the mouth of Mobile Bay to estimate the number of megalopae entering the bay (Fig. 1). The baymouth site was located in sand at the western entrance to Mobile Bay at the eastern end of Dauphin Island. Average salinity here was 24.3 ppt in 1990 and 16.2 ppt in 1991. The airport site was situated in smooth cordgrass Spartina alterniflora marsh on the Mississippi Sound side of Dauphin Island. This site was sampled only during 1990 when the average salinity was 24.0 ppt. The Point aux Pins site was located in an embayment of Mississippi Sound where both seagrass beds and marshes were prevalent. As at the baymouth, mean salinity was higher in 1990 (26.6 ppt) than in 1991 (20.3 ppt). Widgeon grass Ruppia maritima and shoal grass Halodule wrightii dominated seagrass beds, and marshes mostly were comprised of black needlerush Juncus roemerianus and lesser amounts of $S$. alterniflora. The Fowl River site was located just seaward of a $S$. alterniflora marsh midway along the western shore of Mobile Bay. The mean salinity was $24.0 \mathrm{ppt}$ during 1990 and 6.5 ppt in 1991. The delta site was situated in northern Mobile Bay at Meaher State Park and was sampled only during 1990 when salinity averaged 4.8 ppt. Submerged vegetation consisted of tape grass Vallisneria americana and smaller amounts of Myriophyllum and Potamogeton, and marshes were dominated by bullrush Scirpus robustus.
Fig. 1 Mobile Bay and eastern Mississippi Sound, Alabama, USA, showing location of the 5 study sites. The baymouth site is Fort Gaines 
Temporal and spatial patterns of settlement. The timing and magnitude of settlement at these 5 sites were determined daily for approximately 5 or 6 mo during 1990 and 1991. Settlement is defined here as the number of megalopae that were present on collectors and does not imply that megalopae were ready to metamorphose to juveniles. Megalopae are thigmotactic and aggregate on collectors regardless of their competency to metamorphose. Sampling was conducted from June or July through November when most blue crabs reproduce in the Gulf of Mexico (Williams 1984). Settlers were sampled using passive collectors that were made of $38 \mathrm{~cm}$ long PVC pipe $(20 \mathrm{~cm}$ diam.) and replaceable sleeves of 'hog's hair' air conditioning filter (see Metcalf et al. 1995 for details). Three passive collectors were anchored immediately seaward of seagrass beds and marshes (where present) and were floated near the water's surface in less than $1.5 \mathrm{~m}$ of water. Sleeves were replaced daily and returned to the laboratory where they were soaked and rinsed repeatedly in fresh water.

To determine whether most larvae settled during the daytime or at night, collectors were sampied at dusk and dawn at the baymouth. Sampling was conducted during 3 consecutive days during a peak settlement event and during 2 consecutive days when few megalopae settled

A Folsom plankton splitter was used to subsample megalopae when they were especially abundant. Callinectes sapidus megalopae were distinguished from $C$. similis megalopae using the criteria established by Stuck \& Perry (1982)

Meteorological and hydrodynamic data were obtained from a NOAA (National Oceanic and Atmospheric Administration) seaman station that was located next to collectors at the baymouth. Salinity was measured daily at the other 4 sites. Current flow was measured concurrently at the baymouth, Point aux Pins and Fowl River during 7 flood tides in 1991. MarshMcBirney flow meters (model 511) were mounted $0.5 \mathrm{~m}$ away from poles that raised them $1 \mathrm{~m}$ above the substrate. The meters were oriented in the direction of current flow. Current flow was measured hourly from midnight to dawn (06:00 h) during 1 night of peak settlement (3 August). During 6 other nights, current flow was measured twice 1 h apart. Sampling lasted 20 min at $1 \mathrm{~Hz}$. Current speed was calculated by taking the square root of the sum of squared current speeds in the $x$ and $y$ directions

Densities and molt stages of megalopae in the plankton. Plankton tows were taken concurrently at the baymouth, Point aux Pins and Fowl River sites during 3 nights (3 August, 12 August, 15 October) in 1991 to determine densities and molt stages of megalopae. Three $10 \mathrm{~min}$ tows were taken hourly throughout the night. A flow meter was positioned in the mouth (30 $\mathrm{cm}$ ) of each net (335 $\mu \mathrm{m}$ mesh). Each night, 20 megalopae from each site were molt staged following the methods described by Lipcius et al. (1990). Hence, a total of 180 megalopae were staged.

Habitat selection. The ability of settling megalopae to discriminate among habitats was determined twice during 1991. Settlement on different types of substrates was measured during 1 night of peak settlement ( 3 August) and 1 night of light settlement (12 September). Vegetated plots were dug from Ruppia maritima beds and Juncus roemerianus marshes at Point aux Pins and Spartina alterniflora marshes on Dauphin Island. Plots of unvegetated substrate also were dug from marshes on Dauphin Island. Plots were placed in $25 \mathrm{~cm}$ diam. plastic bowls, submerged in aerated water and picked clean of the few megalopae present. Four (12 September) or five (3 August) bowls of each treatment were transplanted into sand in less than $1 \mathrm{~m}$ of water at the baymouth site. Bowls were positioned randomly $2 \mathrm{~m}$ apart and were leveled with the surface of the substrate. $J$, roemerianus averaged 69 shoots at a mean dry weight of $69.0 \mathrm{mg}$ per plot, $S$ alterniflora averaged 38 shoots at $115.6 \mathrm{mg}$ per plot and $R$. maritima consisted of low-lying filaments at $5.5 \mathrm{mg}$ per plot. Plots were removed after $24 \mathrm{~h}$ and were repeatedly bathed in fresh water Megalopae were collected on a sieve and counted

Statistical analysis. Cross-correlation analysis was used to determine whether settlement was related to temperature, onshore-offshore (north-south) wind stress, alongshore (east-west) wind stress or peak wind speed. The Rayleigh test $(r)$ was used to determine whether settlement was related to lunar or tidal amplitude cycles (Batschelet 1981). The mean angle (day of peak settlement) and angular deviation ( $s$, days from peak settlement) were calculated when settlement was nonuniform.

Daily settlement at the baymouth and at each of the other 4 sites was cross-correlated to determine whether or not the timing of settlement was similar among sites. Lags between sites provided an estimate of the time required for larvae to be transported upstream. The Kruskal-Wallis test was used to determine whether or not the number of megalopae in the plankton and settling on collectors differed among sites. This test also was used to determine whether or not current flow at the baymouth, Point aux Pins and Fowl river was similar.

The t-test was used to determine whether or not megalopae primarily settled during the daytime or nighttime. ANOVA followed by the Tukey-Kramer HSD means comparison test was used to determine whether or not megalopae settled more on one type of substrate than another. For both tests, data were log- 
transformed before analysis, and settlement during peak and offpeak recruitment events were analyzed separately to reduce variance.

\section{RESULTS}

\section{Temporal settlement patterns}

Blue crab megalopae recruited to Mobile Bay from offshore waters during every month of the investigation. Callinectes sapidus and C. similis megalopae settled from July through November in 1990 (Fig. 2) and from June through November in 1991 (Fig. 3). Peak settlement by both species of crabs occurred from mid-
July to mid-August in 1990 and from mid-September to mid-October in 1991. Seawater temperature began to decline in mid-September during both years (Figs. 4 \& 5), but settlement and ambient temperatures were correlated fairly well only in 1991 (Figs. 6 \& 7). Settlement of C. sapidus and C. similis was much higher in 1991 than 1990 (Figs. $2 \& 3$ ). Settlement by both species was correlated highly in both years $\left(\mathrm{r}^{2}=0.90\right)$; therefore statistical results are presented only for $C$. sapidus.

Onshore winds and tides delivered Callinectes sapidus and $C$. similis megalopae to Mobile Bay and Mississippi Sound. In 1990, megalopae settled on substrates in Mobile Bay $5 \mathrm{~d}$ after peak onshore (northsouth) winds (Figs. 4 \& 6), especially near minimum amplitude equatorial tides (Figs. 2 \& 8). In 1991,
Fig. 2. Daily settlement by Callinectes sapidus and $C$. similis megalopae relative to lunar and tidal amplitude cycles at 5 sites in Mobile Bay and Mississippi Sound from July through November 1990. (O) Full moons, (-) new moons. The predicted height of daily high tide is also shown
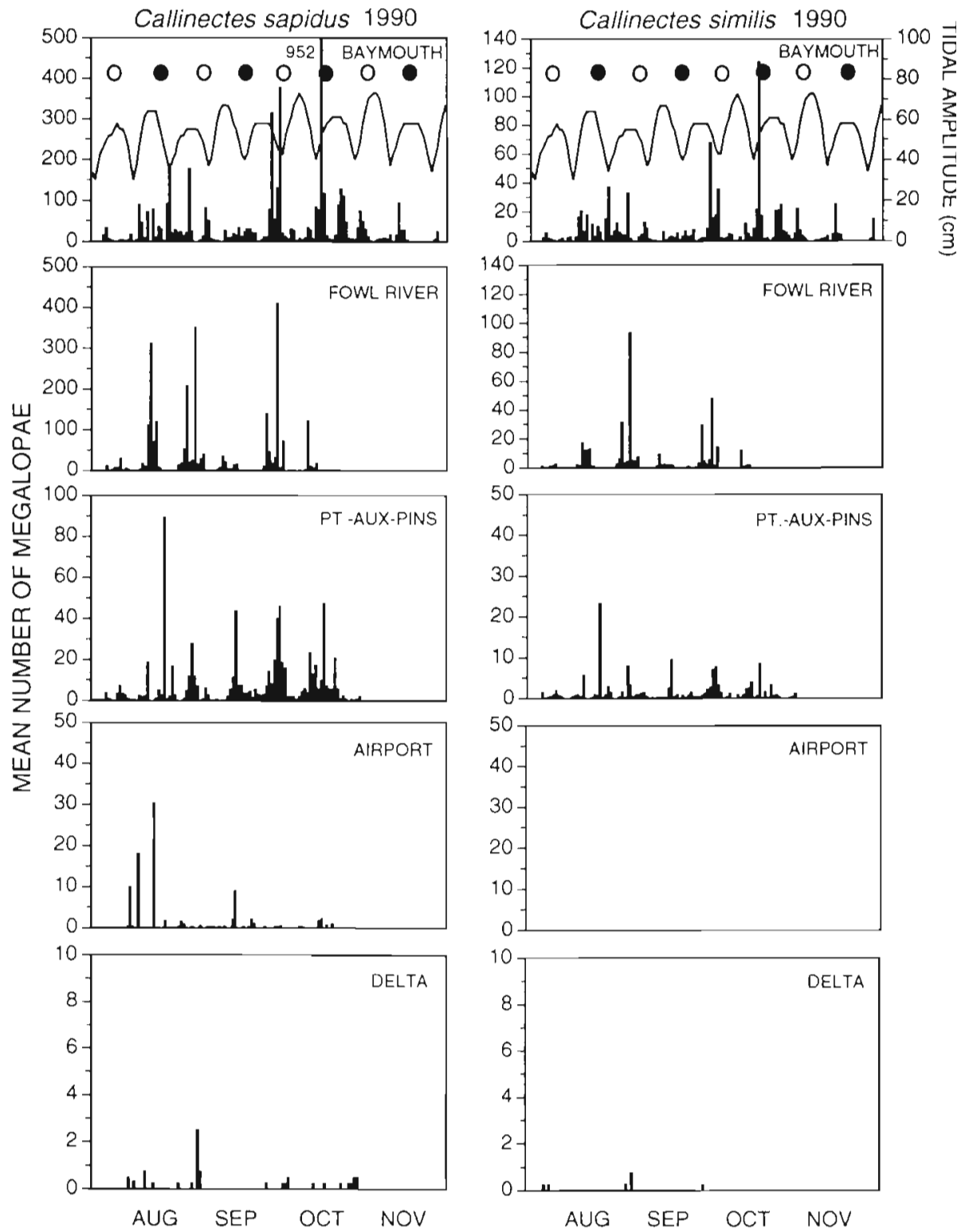

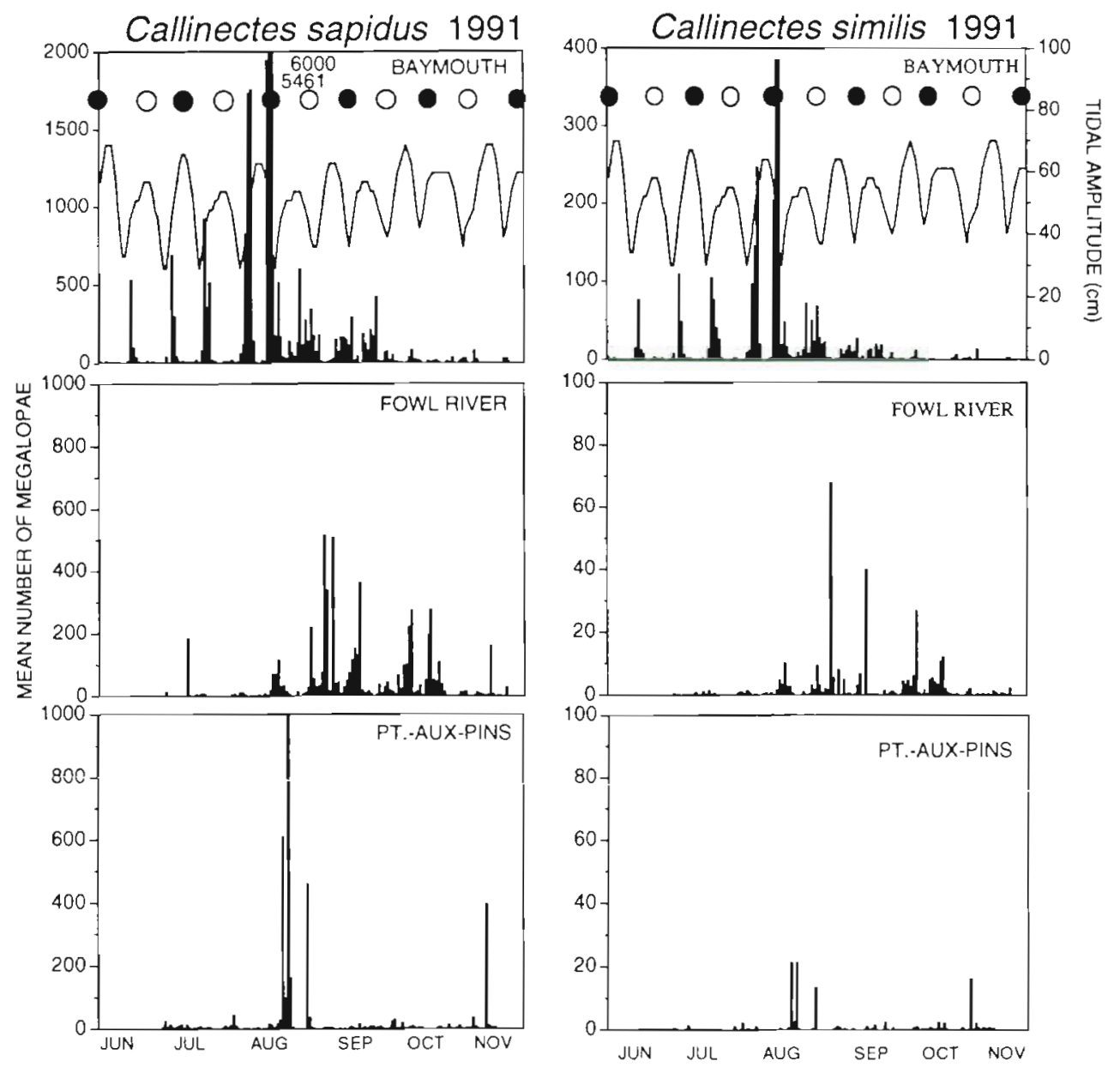

Fig, 3. Daily settlement by Callinectes sapidus and C. siñilis megalopac relative to lunar and tidal amplitude cycles at 3 sites in Mobile Bay and Mississippi Sound from June through November 1991. (O) Full moons, (a) new moons. The predicted height of daily high tide is also shown

onshore winds were light (Fig. 5) and settlement was weakly and negatively correlated with onshore wind stress (Fig 7). Instead, blue crab megalopae recruited biweekly during minimum equatorial tides (Figs. 3 \& 8). Seven biweekly pulses of megalopae entered Mobile Bay from mid-June to mid-September 1991. Approximately 6000 C. sapidus and 4000 C. similis megalopae settled per collector during the largest peak, which is equivalent to about $2500 \mathrm{C}$. sapidus and $1700 \mathrm{C}$. similis megalopae $\mathrm{m}^{-2}$.

Settlement was better synchronized with the tidal amplitude cycle than the lunar cycle, especially during 1991 when winds were light (Figs. 2 \& 3). Peak settlement during both years occurred during equatorial tides (1990: $r=0.36, s= \pm 3.2 \mathrm{~d} ;$ 1991: $r=0.45, s=$ $\pm 2.8 \mathrm{~d}$ ), but it occurred $1 \mathrm{~d}$ after new and full moons in $1990(r=0.29, s= \pm 3.8 \mathrm{~d})$ and $2 \mathrm{~d}$ before quarter moons in $1991(r=0.20, s= \pm 4.3 \mathrm{~d})$. Settlement was not correlated with alongshore (east-west) wind stress (Figs. 4 to 7 ) during either year.

Blue crabs settled on substrates in Mobile Bay during the daytime and nighttime (Fig. 9). More Callinectes sapidus megalopae, C. sapidus first stage crabs and
C. similis megalopae were collected at night during a peak settlement event from 2 to 4 August 1991, although results were not significantly different (C. sapidus megalopae: $F=2.84, \mathrm{df}=1, \mathrm{p}=0.11$; C. sapidus first stage crabs: $F=2.10, \mathrm{df}=1, \mathrm{p}=0.16$; C. similis megalopae: $F=0.001, \mathrm{df}=1, \mathrm{p}=0.97$ ). Megalopae of both species and first instar crabs of $C$. sapidus were collected in similar numbers during the daytime and nighttime on 2 days (15 and 17 October 1991) of light settlement ( $C$. sapidus megalopae: $F=1.21$, $\mathrm{df}=$ $1, p=0.31 ; C$. sapidus first stage crabs: $F=1.25, \mathrm{df}=1$, $\mathrm{p}=0.31 \mathrm{i}$. similis megalopae: $F=0.53, \mathrm{df}=1, \mathrm{p}=$ $0.49)$. However, significantly more $C$. sapidus megalopae $(F=11.35, \mathrm{df}=1, \mathrm{p}=0.02)$ and first stage crabs $(F=92.91, \mathrm{df}=1, \mathrm{p}<0.0001)$ settled at night on $3 \mathrm{Au}-$ gust when high tides occurred in darkness at 05:00 h.

\section{Spatial settlement patterns}

During both years, Callinectes sapidus (1990: $H=$ 268.18, df $=4, \mathrm{p}<0.001 ; 1991: H=66.06, \mathrm{df}=2, \mathrm{p}<$ 0.001 ) and $C$. similis (1990: $H=178.37, \mathrm{df}=4, \mathrm{p}<0.001$; 
Fig. 4. Callinectes sapidus. Daily settlement by megalopae (filled black areas) relative to sea surface temperature, north-south wind stress, east-west wind stress and peak wind velocity (dashed lines) at the mouth of Mobile Bay from July through November 1990. Environmental variables are shown for late June and July because data were analyzed for lags in settlement as long as $40 \mathrm{~d}$ relative to water temperature, wind stress and wind velocity
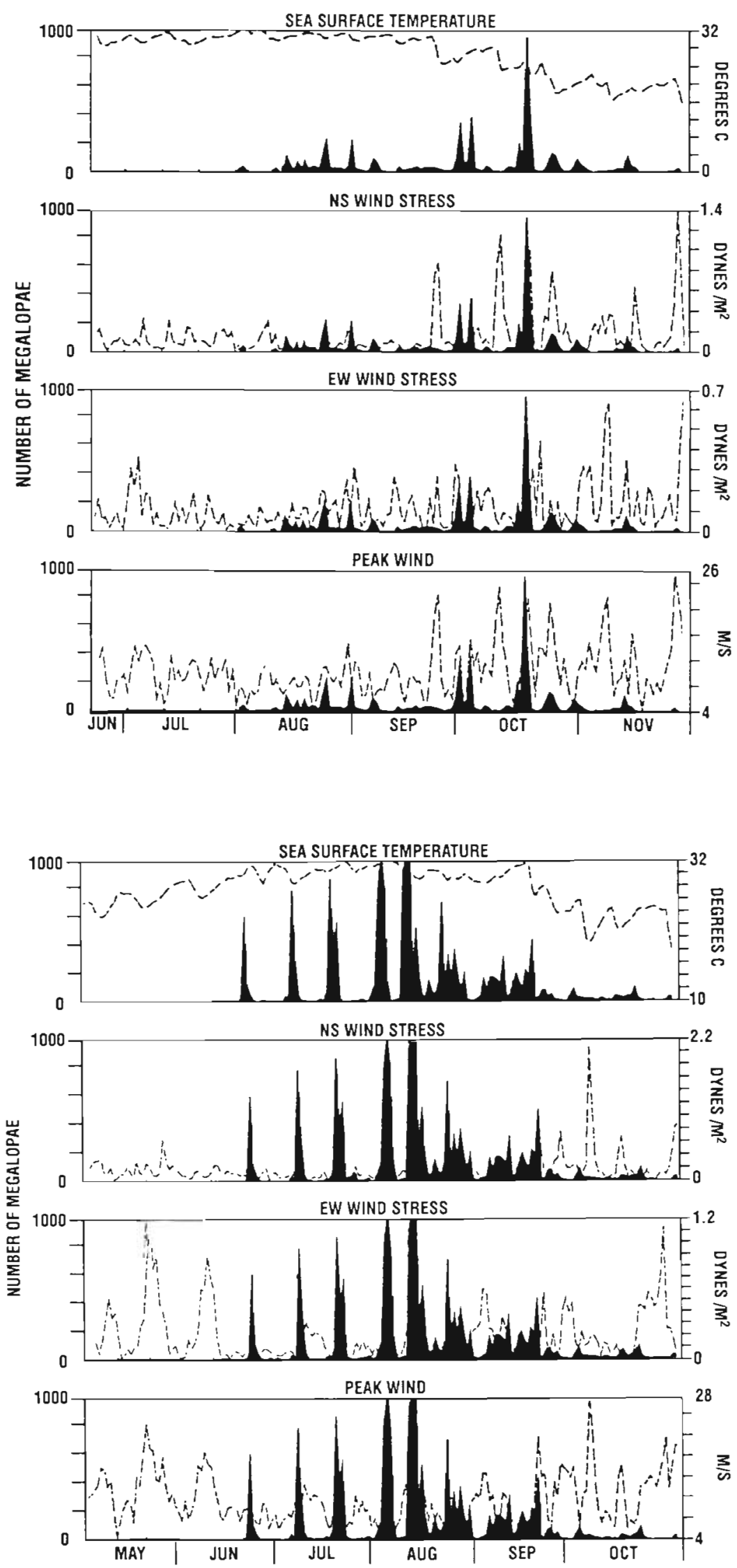

Fig. 5. Callinectes sapidus. Daily settlement by megalopae (filled black areas) relative to sea surface temperature, north-south wind stress, east-west wind stress and peak wind velocity (dashed lines) at the mouth of Mobile Bay from mid-June to November 1991. Environmental variables are shown for May because data were analyzed for lags in settlement as long as $40 \mathrm{~d}$ relative to water temperature, wind stress and wind velocity 

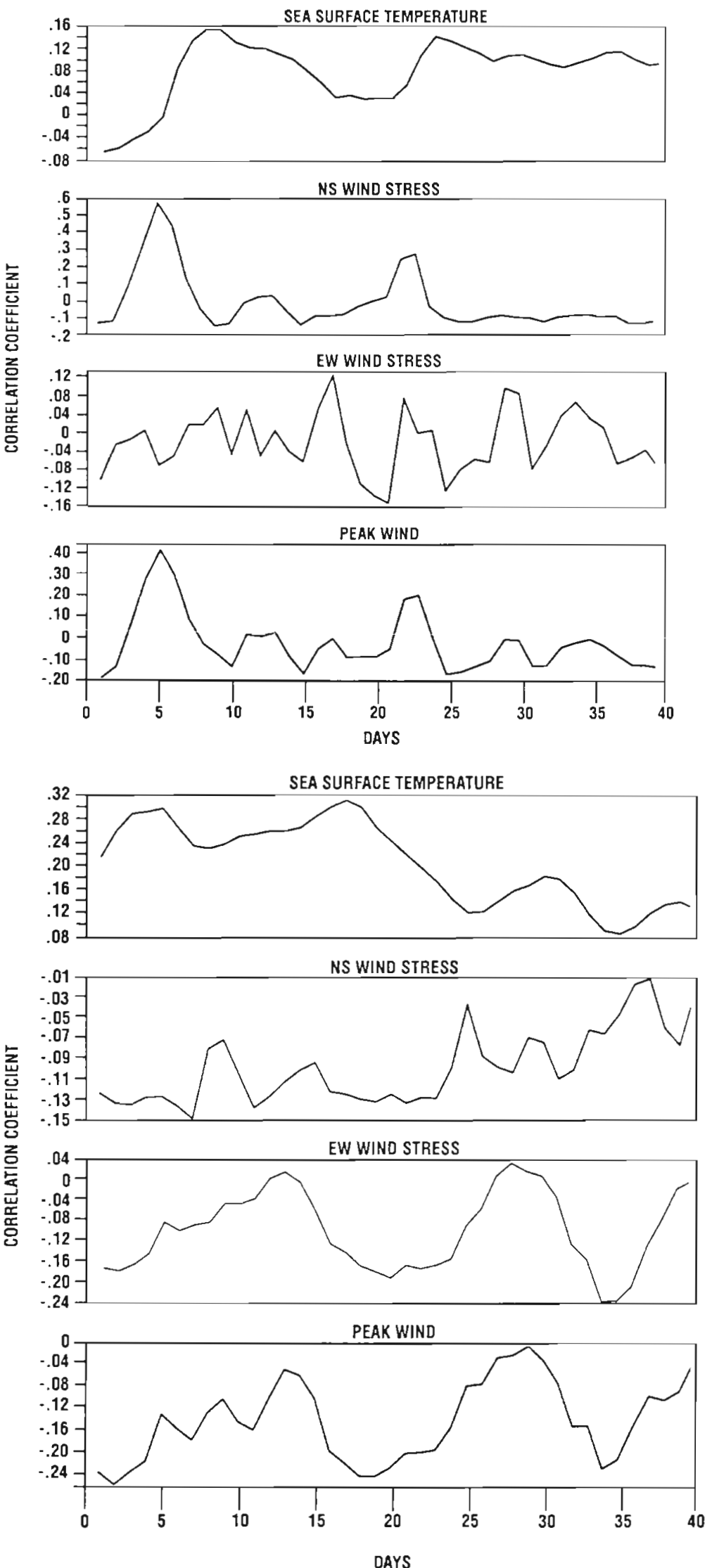

Fig. 6. Callinectes sapidus. Cross-correlations of daily settlement by megalopae at the mouth of ivobile Bay in 1990 with sea surface temperature, north-south wind stress, east-west wind stress and peak wind velocity. Data were analyzed for lags in settlement as long as $40 \mathrm{~d}$
Fig. 7 Callinectes sapidus. Cross-correlations of daily settlement by megalopae at the mouth of Mobile Bay in 1991 with sea surface temperature, north-south wind stress, east-west wind stress and peak wind velocity. Data were analyzed for lags in settlement as long as $40 \mathrm{~d}$ 

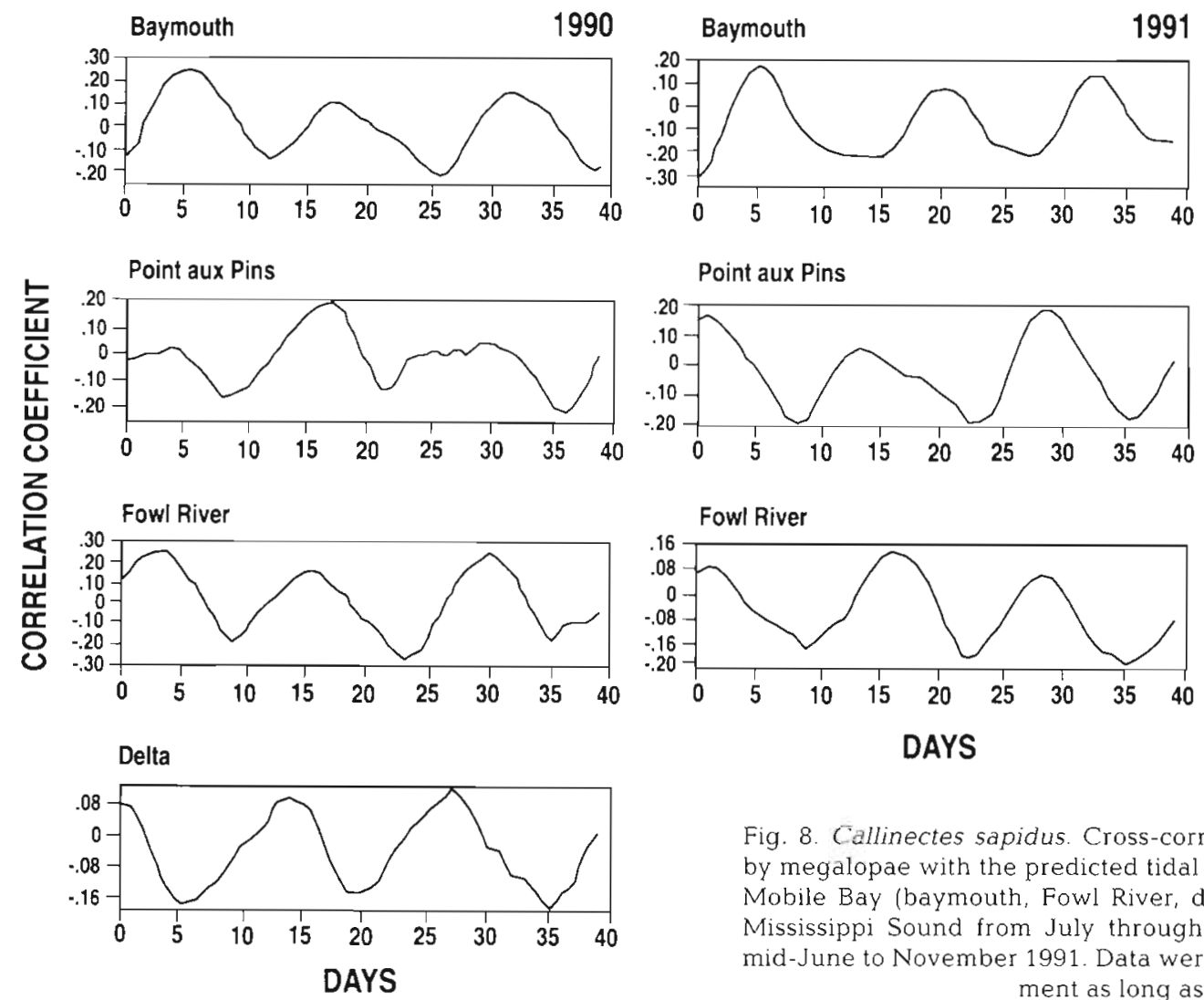

Fig. 8. Callinectes sapidus. Cross-correlations of daily settlement by megalopae with the predicted tidal amplitude cycle at 3 sites in Mobile Bay (baymouth, Fowl River, delta) and Point aux Pins in Mississippi Sound from July through November 1990 and from mid-June to November 1991. Data were analyzed for lags in settlement as long as $40 \mathrm{~d}$

1991: $H=113.34, \mathrm{df}=2, \mathrm{p}<0.001$ ) megalopae settled most abundantly at the mouth of Mobile Bay, declined toward the middle of the estuary (Fowl River) and were infrequent at the head of the estuary (delta) (Table 1 . Fig. 2). This trend was particularly pronounced in 1991 when even fewer $C$. sapidus and $C$. similis megalopae settled at Fowl River than at the baymouth. Fewer megalopae of both species settled at Point aux Pins than at the baymouth during both years. Settlement by both species also tended to be greater at Fowl River than Point aux Pins. Settlement by the airport nearly was as sparse as at the head of the estuary in 1990.

Abundances of planktonic megalopae and settlers were similar among sites during 1991. Callinectes sapidus $(H=15.87, \mathrm{df}=2, \mathrm{p}<0.001)$ and $C$. similis $(H=$ 13.93, df $=2, p<0.001$ ) megalopae were most abundant in the plankton at the baymouth and progressively declined upstream (Fig. 10). Most first instar crabs were collected from the plankton at Point aux Pins $(H=5.26, \mathrm{df}=2, p=0.07)$, few were taken at Fowl River and none was collected from the baymouth (Fig 10).

More megalopae may have been delivered to the baymouth where currents were stronger than at other sites (Table 2). Maximum and mean current speeds at the baymouth usually were 2 to 10 times higher than at
Point aux Pins or Fowl River. Flow at the latter 2 sites was similar. Measurements were not taken at the delta or airport but flow appeared to be even slower at these sites.

Megalopae of all developmental stages entered the baymouth, but later molt stages became increasingly abundant upstream (Fig. 11). Late molt stages of blue crab megalopae were more prevalent at Point aux Pins and were even more abundant at Fowl River than at the baymouth, presumably because it took them longer to reach these sites. This is suggested by the lagged correlations between settlement at the baymouth and more shoreward sites (Fig. 8). Callinectes sapidus megalopae settled at about the same time to 3 d later at Point aux Pins (1990: $r^{2}=0.42 ; 1991: r^{2}=$ 0.47), 2 to 3 d later at Fowl River (1990: $r^{2}=0.25 ; 1991$ : $\left.r^{2}=0.07\right)$, and $3 \mathrm{~d}$ later at the delta $\left(r^{2}=0.10\right)$. Settlement at all 5 sites occurred at 15 d intervals during both years, which suggests that tidal currents transported megalopae into Mobile Bay and Mississippi Sound biweekly and carried them to the head of the estuary 3 d later.

Megalopae in early stages of development were more common in August than they were in October at the baymouth (Fig. 11). Stage C and D1 megalopae were common at the baymouth in August but were 

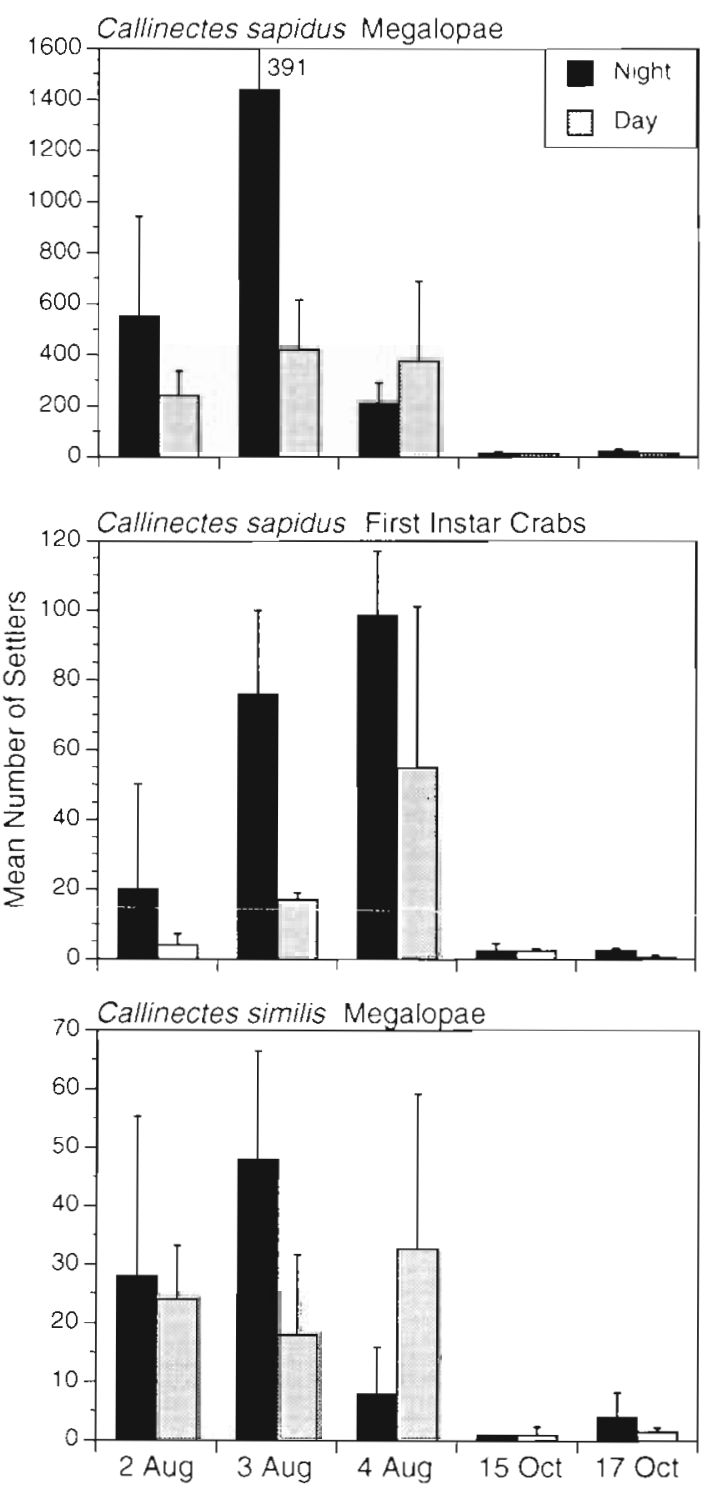

Fig. 9. Settlement by Callinectes sapidus megalopae and first instar crabs and $C$. similis megalopae during the nighttime and daytime at the mouth of Mobile Bay on 5 days during 1.990
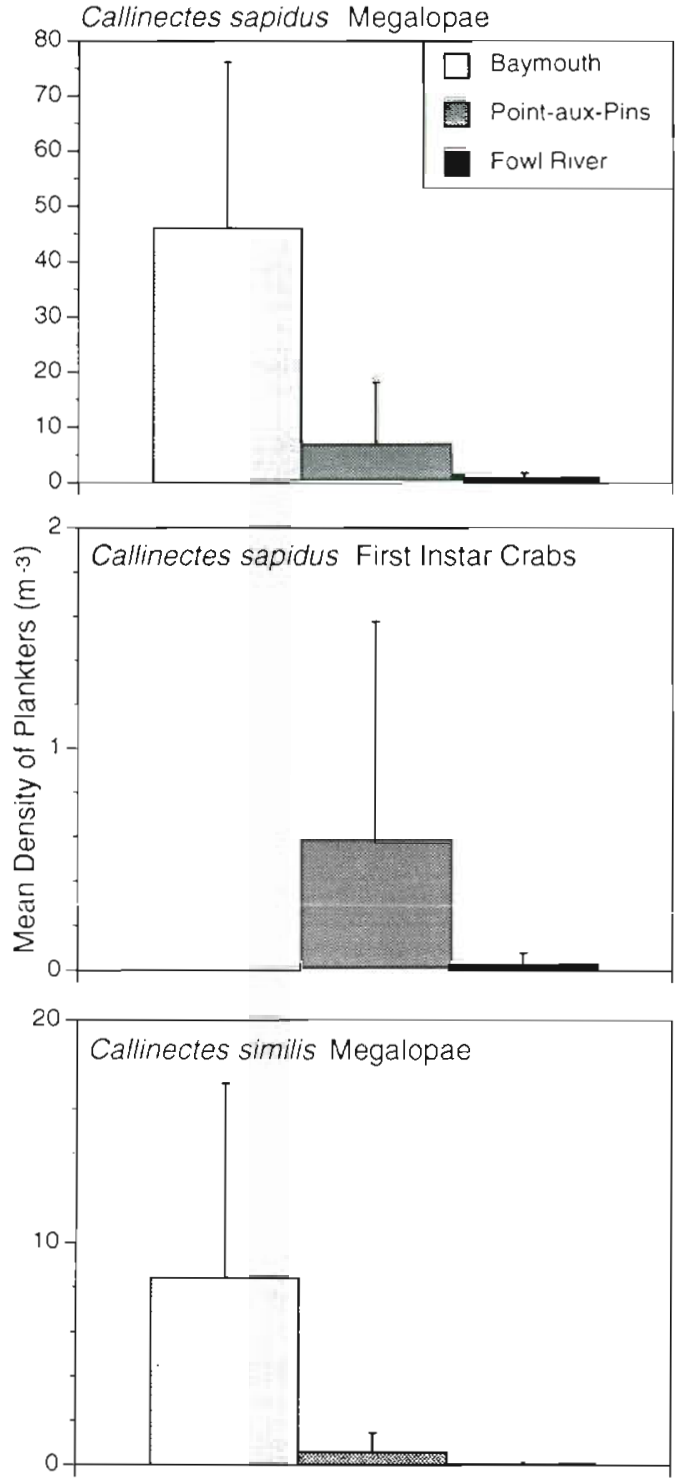

Fig. 10. Mean density $\left(\mathrm{m}^{-3}\right)$ of Callinectes sapidus megalopae and first instar crabs and $C$. similis megalopae collected from the plankton at the baymouth and Fowl River in Mobile Bay and Point aux Pins in Mississippi Sound during 1991
Table 1. Percentage of Callinectes sapidus and C. simulis megalopae settling at 5 sites in Mobile Bay and Mississippi Sound from June through November 1990 and at 3 of these sites from July through November 1991

\begin{tabular}{|lcccccc}
\hline \multirow{2}{*}{$\begin{array}{l}\text { Species } \\
\text { Year }\end{array}$} & \multicolumn{5}{c}{ Site } \\
& & Baymouth & Point aux Pins & Airport & Fowl River Delta \\
\hline C. sapidus & 1990 & 56.8 & 9.2 & 1.1 & 32.7 & 0.1 \\
& 1991 & 69.8 & 18.8 & - & 11.4 & - \\
& & & & & & \\
C. similhs & 1990 & 63.0 & 1.0 .1 & 0 & 26.8 & 0.1 \\
& 1991 & 87.0 & 3.4 & - & 9.7 & - \\
\end{tabular}

absent in October, and stage D5 megalopae were rare in August but were common in October.

Regardless of whether settlement was heavy in August $(F=53.66, \mathrm{df}=17, \mathrm{p}<$ $0.001)$ or light in September $(F=8.73, \mathrm{df}=$ $15, p<0.01$ ), megalopae preferred to settle on vegetated plots. More than 4 times as many Callinectes sapjdus megalopae settled on Spartina alterniflora than on Ruppia maritima or Juncus roemerianus in August (Fig. 12), although this trend was 

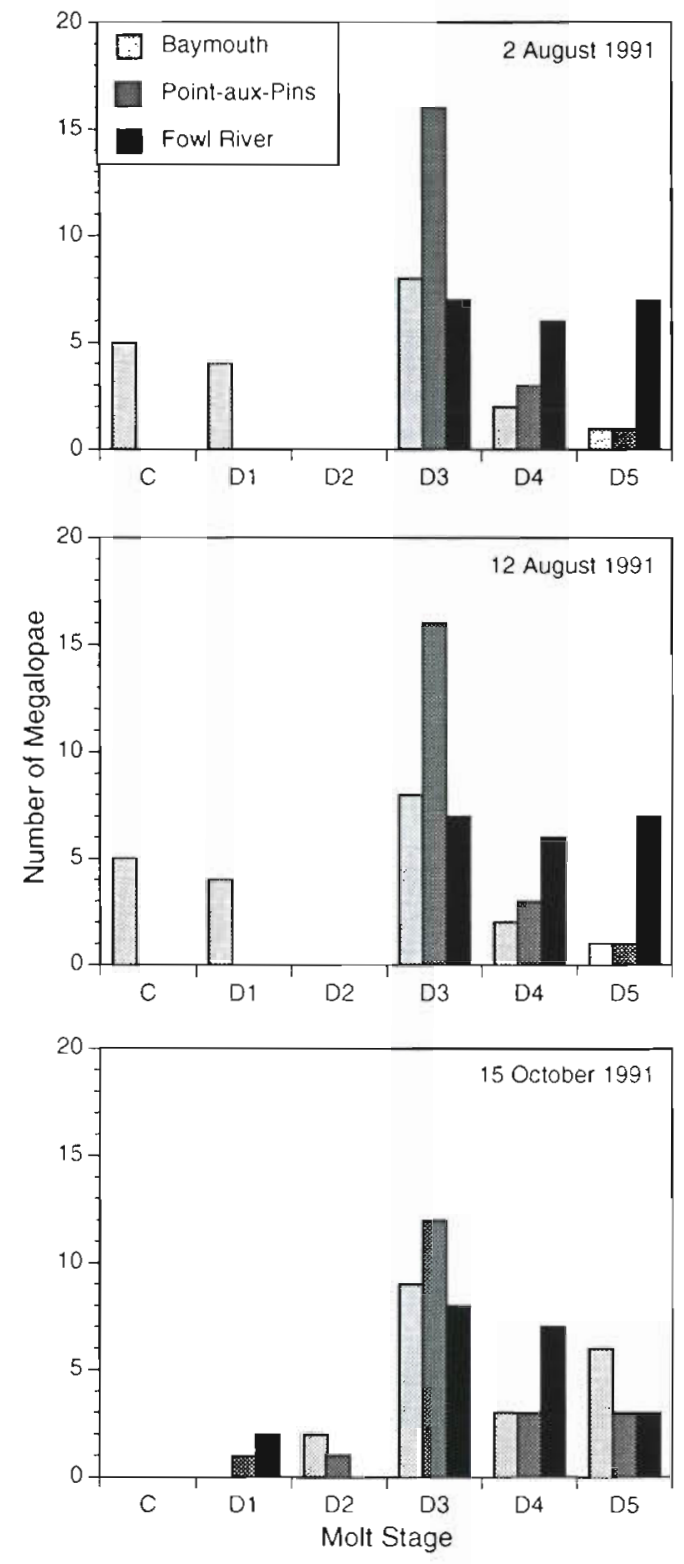

Fig. 11. Molt stage of 20 Callinectes sapidus megalopae collected from the plankton at the baymouth and Fowl River in Mobile Bay and Pont aux Pins in Mississippi Sound during 3 nights in 1991 The youngest megalopae are in stage $C$ of the molt cycle and the oldest ones occur in stage D5

not significant. More first instar crabs $C$ sapidus $(H=$ 1.94, $\mathrm{df}=2, \mathrm{p}=0.38)$ and $C$. similis megalopae $(H=1.98$, $\mathrm{df}=2, \mathrm{p}=0.37$ ) also settled on $S$. alterniflora than the other plants, but these differences also were not significant. The comparatively broad blades of $S$. alterniflora extended throughout the water column and provided more surface area than shorter round $J$. roemerianus shoots or the sparse low-lying filaments of $R$. maritima. This also is reflected in the different dry weights of the plants that were used in these experiments.
A. different nonsignificant trend was found $41 \mathrm{~d}$ later when settlement on vegetated plots was light. Six times more megalopae of Callinectes sapidus occurred on Ruppia maritima than on Spartina alterniflora, and the first few instar crabs of this species occurred only on $R$. maritima (Fig. 12). Only a few C. similis megalopae settled in September, and these occurred only on Juncus roemerianus

\section{DISCUSSION}

\section{Settlement in Mobile Bay versus Atlantic estuaries}

Although settlement by Callinectes sapidus megalopae has been studied along the Atlantic coast of the USA, this is one of the first investigations that has been conducted on the Gulf coast. Several striking differences are apparent. Peak settlement was 1 or 2 orders of magnitude greater in Mobile Bay than in estuaries along the Atlantic coast (Olmi et al. 1990, van Montfrans et al. 1990, 1995, Rabalais et al. 1995), except during an unusual year in Charleston Harbor, South Carolina (Boylan \& Wenner 1993). Settlement usually may be greater in the Gulf due to higher abundances of adults occurring in this warmer climate. The Gulf of Mexico is near the center of the species' range, which usually extends from Massachusetts to northern Argentina (Williams 1984)

Table 2. Current flow at 3 sites in Mobile Bay and Mississippi Sound during 7 nocturnal flood tides in 1991

\begin{tabular}{|c|c|c|c|}
\hline \multirow[t]{2}{*}{ Date } & \multirow[t]{2}{*}{ Site } & \multicolumn{2}{|c|}{ Current speed $\left(\mathrm{cm} \mathrm{s}^{-1}\right)$} \\
\hline & & Max. & Mean \\
\hline \multirow[t]{3}{*}{3 Aug } & Baymouth & 7.2 & 3.0 \\
\hline & Point aux Pins & 2.9 & 1.3 \\
\hline & Fowl River & 4.6 & 16 \\
\hline \multirow{3}{*}{$29 \mathrm{Sep}$} & Baymouth & 22.4 & 10.7 \\
\hline & Point aux Pins & 4.5 & 2.0 \\
\hline & Fowl River & 2.8 & 1.2 \\
\hline \multirow[t]{3}{*}{$4 \mathrm{Oct}$} & Baymouth & 4.5 & 2.1 \\
\hline & Point aux Pins & 2.8 & 1.6 \\
\hline & Fowl River & 2.8 & 1.1 \\
\hline \multirow[t]{3}{*}{$5 \mathrm{Oct}$} & Baymouth & 26.1 & 18.4 \\
\hline & Point aux Pins & 6.3 & 2.7 \\
\hline & Fowl River & 4.5 & 3.3 \\
\hline \multirow[t]{3}{*}{$11 \mathrm{Oct}$} & Baymouth & 10.0 & 4.3 \\
\hline & Point aux Pins & 4.5 & 4.3 \\
\hline & Fowl River & 4.5 & 1.9 \\
\hline \multirow[t]{3}{*}{12 Oct } & Baymouth & 12.6 & 6.3 \\
\hline & Point aux Pins & 4.5 & 1.9 \\
\hline & Fowl River & 10.4 & 5.7 \\
\hline \multirow[t]{3}{*}{20 Oct } & Baymouth & 8.9 & 4.6 \\
\hline & Point aux Pins & 4.5 & 1.6 \\
\hline & Fowl River & 6.3 & 1.9 \\
\hline
\end{tabular}



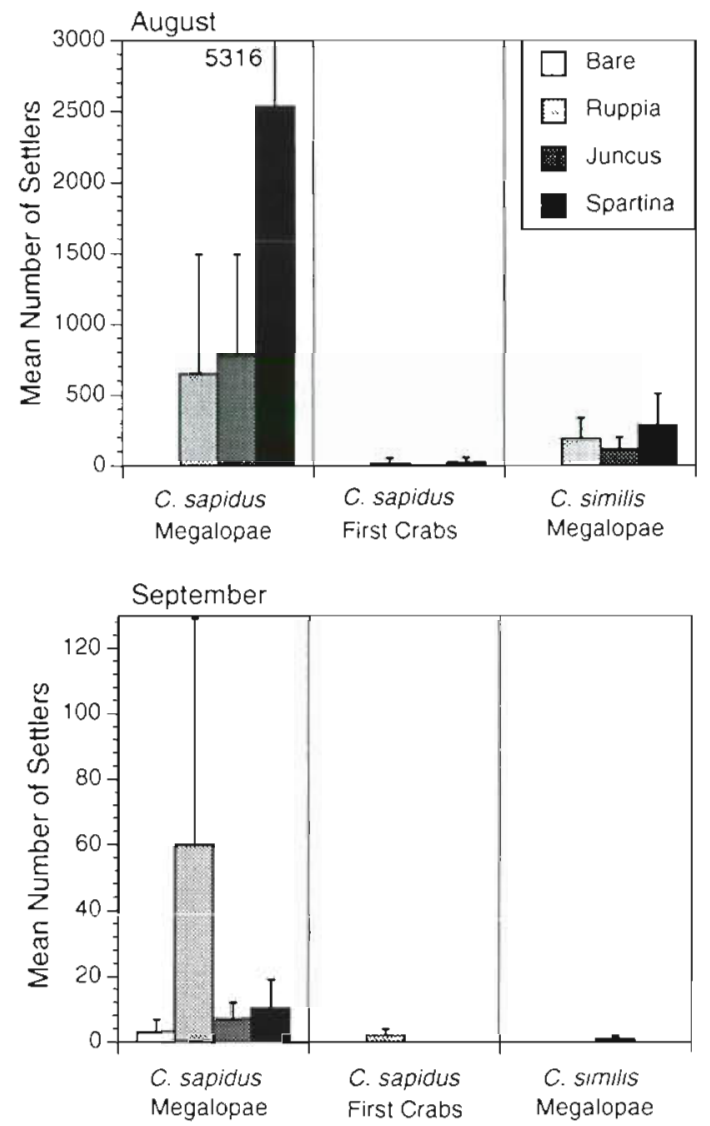

Fig. 12. Settlement by Callinectes sapidus megalopae and first instar crabs and $C$. similis megalopae on 4 types of substrates that were transplanted to sandy habitats at the mouth of Mobile Bay during 1991. Settlement was heavy on 3 August and was light on 12 September

Moderate temperatures in the Gulf also may have favored protracted reproduction by Callinectes sapidus. Blue crab megalopae recruited to Mobile Bay and Mississippi Sound throughout the summer and fall when this study was conducted. Megalopae probably settle nearly year-round because ovigerous females of $C$. sapidus and C. similis have been collected in Mobile Bay and the Gulf of Mexico throughout most of the year (Williams 1984, Hsueh et al. 1993). In colder climates along the Atlantic coast of the USA, C. sapidus megalopae generally settle only from summer through autumn (Williams 1984, Boylan \& Wenner 1993, van Montfrans et al. 1995).

Along both coasts, onshore winds and tides often facilitate recruitment of blue crab megalopae to estuarine nursery habitats (Rabalais et al. 1995, van Montfrans et al. 1995). Winds have a particularly strong influence on water exchange between the Gulf of Mexico and estuaries where tidal amplitudes are low (Smith 1977, Swenson \& Chuang 1983, Schroeder \&
Wiseman 1986, Stumpf et al. 1993). In 1991, peak settlement was correlated with onshore winds, which prevail during summer and early autumn (Ward 1980, Schroeder \& Wiseman 1986). These winds may transport megalopae shoreward in the neuston until they reach the front of the plume flowing from Mobile Bay. Megalopae then would be subducted with surface currents beneath the buoyant plume and advected into the bay (Gelfenbaum \& Stumpf 1993). Peaks in settlement could occur if megalopae aggregate near estuarine fronts until winds begin blowing onshore.

Although onshore winds probably facilitated transport of blue crab megalopae into Mobile Bay, tides may be more important because megalopae recruited effectively even when onshore winds were light. Indeed, settlement was much greater during 1991 when onshore winds were less common and lighter. During both years, blue crab megalopae consistently recruited to Mobile Bay near minimum amplitude equatorial tides. The biweekly periodicity in recruitment was more closely associated with the tidal amplitude cycle than the lunar cycle, which suggests that tides rather than the moon regulate recruitmont to estuaries. This distinction is possible along the Gulf coast, where the declination of the moon rather than planetary alignment governs the tidal amplitude cycle.

Most blue crab megalopae also recruited during nocturnal minimum amplitude flood tides in Charleston Harbor, South Carolina (Boylan \& Wenner 1993). Recruitment may be favored during minimum amplitude tides at both locales due to strong stratification (Linden \& Simpson 1988, Nunes Vaz et al. 1989, Sharples \& Simpson 1993). At that time, surface waters flow offshore and deeper residual currents flow onshore, which would facilitate onshore movement of megalopae that were subducted beneath the estuarine plume. Exchange between coastal and estuarine waters is reduced when the water column is mixed during maximum amplitude tides. Therefore, recruitment may be greatest in Mobile Bay and Charleston Harbor during minimum amplitude tides when prevailing light to moderate onshore winds would subduct neustonic megalopae beneath the estuarine plume and residual currents would advect them onshore.

Peak settlement by blue crabs in Chesapeake Bay occurs during maximum amplitude flood tides when mixing is greatest (Olmi et al. 1990, van Montfrans et al. 1990, Olmi 1995). This shift in timing suggests that multiple or perhaps other tidally related processes may facilitate recruitment of megalopae to estuaries. One possibility is that internal waves transport megalopae onshore, because spatial variation in the timing of peak settlement relative to the tidal amplitude cycle has been observed for other animals (Pineda 1991). 
Plankton and settlement studies on both coasts suggest that most blue crab megalopae move landward during nocturnal flood tides (Epifanio et al. 1984, Olmi et al. 1990. De Vries et al. 1994, Olmi 1994, J. M. Schell \& S. G. Morgan unpubl.). However, settlement during the daytime was more common along the Gulf than the Atlantic coast. Megalopae may have timed swimming more precisely on the Atlantic coast, where the 2 flood tides per day usually occur either exclusively during the nighttime or daytime. In this case, swimming simply may not be initiated during daytime flood tides. Along the coast of Alabama, the 1 flood tide per day is twice as long and often occurs during darkness and daylight. Therefore, swimming begun during darkness may continue after dawn as tides continue to flood.

\section{Postlarval supply and habitat preferences}

Callinectes sapidus megalopae were much more abundant than C. similis in Mobile Bay and Mississippi Sound perhaps because more larvae were released or because megalopae preferred to settle in estuarine habitats. $C$. sapidus females collectively may have released more larvae because they are about an order of magnitude more fecund $\left(2.1\right.$ to $3.2 \times 10^{6}$ vs 2.4 to $5.5 \times 10^{5}$ eggs per brood) than smaller $C$. similis females (Hsueh et al. 1993). Whether or not ovigerous $C$. sapidus females also were more abundant than egg-bearing $C$. similis females in the northern Gulf of Mexico is unknown.

Alternatively, interspecific differences in abundance of megalopae may be explained by habitat preferences. Callinectes similis does not osmoregulate as well as C. sapidus and probably prefers deeper high salinity waters (Engel 1977, Hsueh 1992). This is evident in the distributions of megalopae, juveniles and adults of $C$. similis. Not only were megalopae of C. similis less common than C. sapidus in Mobile Bay, but more of them occurred at the baymouth than at more landward sites during both years. This matches the distributions of the youngest juveniles of $C$. similis that occur in open unvegetated habitats near the mouth of Mobile Bay and adjacent coastal waters where the salinity usually is greater than $25 \mathrm{ppt}$ (Hsueh et al. 1993). Most juveniles that settle in the bay probably migrate to deeper coastal waters, because adults largely occupy coastal waters and ovigerous females occur there exclusively (Hsueh et al. 1993).

In contrast, Callinectes sapidus appears to depend on wetlands as nursery grounds, because environmental cues from marshes accelerate metamorphosis (Wolcott \& De Vries 1994) and the smallest juveniles occur near marshes rather than in deeper open waters of the bay (Hsueh et al. 1993, Heck et al. unpubl.). Our study suggests that settling megalopae primarily maintain this distribution by discriminating among habitats within Mobile Bay.

On a broad scale, most Callinectes sapidus megalopae settled on collectors at the baymouth, fewer settled in the middle of the bay and very few megalopae settled at the head of the bay. Most megalopae may have settled in the lower estuary simply because they first encountered suitable habitat there. However, this is unlikely to be the sole explanation of this trend because megalopae penetrate much farther than $50 \mathrm{~km}$ into larger estuaries. For instance, megalopae settled abundantly at Tangier Island, which is $90 \mathrm{~km}$ from the mouth of Chesapeake Bay (van Montfrans et al. 1995). We suggest that the gradual decline in settlement upstream primarily resulted because $C$. sapidus megalopae survive better and grow faster at high salinities (Kalber 1970, Costlow 1976) and prefer to settle in the lower bay. Although it took only 2 to $3 \mathrm{~d}$ to travel from the mouth of Mobile Bay to the head of the estuary, few megalopae settled there, presumably because they survive poorly at 5 ppt (Costlow 1976). Megalopae also survive poorly at $10 \mathrm{ppt}$, which may explain the proportionally lower settlement at Fowl River than at the baymouth during the second year of the study when salinity averaged $6.5 \mathrm{ppt}$. In contrast, settlement probably is much greater at Tangier Island because the mean salinity is about 3 times higher, 14.7 to 18.8 ppt (van Montfrans et al. 1995), than at the head of Mobile Bay. Thus, fewer megalopae may have settled in tape grass beds and bullrush marshes at the delta and smooth cordgrass marshes at Fowl River due to salinity preferences of megalopae.

The ability of megalopae to discriminate among habitats in the lower bay is less certain. Differential transport rather than habitat selection primarily appears to determine the abundance of settlers among high salinity habitats. Currents consistently delivered more megalopae to some sites than others. Currents were stronger at the baymouth site and consistently delivered many more megalopae to this site than to the quiet backwaters near the airport and Point aux Pins. Thigmotactic megalopae had little difficulty settling on collectors at the baymouth despite the stronger currents. Thus, delivery by currents rather than passive deposition in quiet backwaters more likely determines where megalopae settle in the lower bay.

Although physiological tolerances and current flow both apparently affect the broad-scale distributions of juveniles, megalopae may discriminate between habitats once they arrive at a site. Blue crab megalopae are strong swimmers that can orient into the flow and swim upstream at low to moderate flow velocities (Luckenbach \& Orth 1992). This apparently enabled mega- 
lopae to select vegetated rather than unvegetated plots.

Evidence that megalopae discriminated among plants was inconclusive, but the strong nonsignificant trends warrant further investigation. During September, over 6 times more Callinectes sapidus megalopae settled on Ruppia maritima than any other plant despite its small surface area. Therefore, behavior rather than postsettlement mortality may explain the higher densities of young juveniles in seagrass beds than marshes (Orth \& van Montfrans 1987, Thomas et al. 1990). This is further suggested by the similar mortality rates of young juveniles that were measured in these habitats (Heck et al. unpubl.). However, the same trend was not obtained in August when over 4 times more megalopae settled on Spartina alterniflora. The differences in settlement patterns on the 2 dates could have resulted if fewer megalopae were ready to metamorphose in August. If so, numerous early stage megalopae may have clung to $S$. alterniflora blades in passing due to the greater surface area provided by these plants, whereas the few late stage megalopae primarily may have sought seaylass in preparation for metamorphosis. Although megalopae were not staged in September, far fewer of them were ready to metamorphose in August than October, providing support for this explanation (Fig. 11). Relatively few megalopae settled on Juncus roemerianus at either time perhaps because these plants provided neither large surface areas for settlement nor appropriate settlement cues.

In conclusion, both postlarval supply and habitat selection appeared to determine the initial abundances of blue crabs in Mobile Bay and Mississippi Sound. Blue crab megalopae settled in very high densities in the lower estuary during nocturnal equatorial flood tides and onshore winds. Physiological tolerances probably ensured that most blue crab megalopae settled in the lower bay. Currents delivered more megalopae to some areas than others in the lower bay, and Callinectes sapidus megalopae preferred to settle in vegetated than unvegetated habitats. However, it remains uncertain whether megalopae select seagrass beds rather than marshes once they arrive at a site. Predation on recent settlers quickly damped differences in juvenile abundances among sites regardless of initial settlement densities (Heck et al. unpubl.). Thus, differential transport and habitat preferences of megalopae both determined the initial densities of settlers, but there was little evidence of density-dependent postsettlement mortality in this population. Early postsettlement mortality by predators rather than postlarval supply may limit population sizes of blue crabs in the northern. Gulf of Mexico
Acknowledgements. We thank Jill Busby, Melanie Mallon, Matt Williams, Todd Bowen, Barbara Randall, Tim Thibault and Mario Tamburri for providing technical assistance. Financial support was provided by NOAA Marine Fisheries Initiative (MARFIN grant number NA90AAHMF761). This is contribution number 274 of the Marine Environmental Sciences Consortium

\section{LITERATURE CITED}

Armonies W, Hellwig-Armonies M (1992) Passive settlement of Macoma balthica spat on tidal flats of the Wadden Sea and subsequent migration of juveniles. Neth J Sea Res 25 $371-378$

Batschelet E (1981) Circular statistics in biology. Academic, New York

Boehlert GW, Mundy BC (1988) Roles of behavioral and physical factors in larval and juvenile fish recruitment to estuarine nursery areas. Am Fish Soc Symp 3:51-67

Boesch DF, Turner RE (1984) Dependence of fishery species on salt marshes: the role of food and refuge. Estuaries 7 $460-468$

Boylan JM, Wenner EL (1993) Settlement of brachyuran megalopae in a South Carolina, USA, estuary. Mar Ecol Prog Ser 97:237-246

Butman CA (1989) Sediment-trap experiments on the importance of hycirodynanical processes in distributing settlirig invertebrate larvae in near bottom waters. $J$ exp mar Biol Ecol 134:37-88

Connell JH (1985) The consequences of variation in initial settlement vs. post-settlement mortality in rocky intertidal communities. J exp mar Biol Ecol 93:11-45

Costlow JD Jr (1976) The effect of salinity and temperature on survival and metamorphosis of megalops of the blue crab Callinectes sapidus. Helgoländer wiss Meeresunters 15 $84-97$

Costlow JD Jr, Bookhout CG (1959) The larval development of Callinectes sapidus Rathbun reared in the laboratory Biol Bull 116:373-396

De Vries MC, Tankersley RA, Forward RB Jr, Kirby-Smith WW, Luettich RA Jr (1994) The abundance of estuarine crab larvae is associated with tidal hydrologic variables Mar Biol 118:403-418

Eckman J (1987) The role of hydrodynamics in recruitment, growth, and survival of Argopecten irradians (L) and Anomia simplex (D'Orbigny) within eelgrass meadows. $\mathrm{J}$ exp mar Biol Ecol 106:165-191

Eleuterius CK (1978) Classification of Mississippi Sound as to estuary type by vertical salinity structure. J Miss Acad Sci $23: 23-32$

Engel DW (1977) Comparison of the osmoregulatory capabilities of two portunid crabs, Callinectes sapidus and C. simijus. Mar Biol 41:275-279

Epifanio CE (1988) Transport of invertebrate larvae between estuaries and the continental shelf. Trans Am Fish Soc Symp Ser 3:104-114

Epifanio CE, Masse AK. Garvine RW (1989) Transport of blue crab larvae by surface currents off Delaware Bay, USA. Mar Ecol Prog Ser 54:35-41

Epifanjo CE, Valenti CC, Pembroke A (1984) Dispersal and recruitment of blue crab larvae in Delaware Bay, USA. Estuar coast Shelf Sci 18:1-12

Forrester GE (1990) Factors influencing the juvenile demography of a coral reef fish. Ecology 71:1666-1681

Gaines S, Brown S, Roughgarden J (1985) Spatial variation in larval concentrations as a cause of spatial variation in set- 
tlement for the barnacle, Balanus glandula. Oecologia 67 $267-272$

Gelfenbaum G, Stumpf RP (1993) Observations of currents and density structure across a buoyant plume front. Estuaries $16: 40-52$

Goodrich DM, van Montfrans J, Orth RJ (1989) Blue crab megalopal influx to Chesapeake Bay: evidence for a winddriven mechanism. Estuar coast Shelf Sci 29:247-260

Hsueh PW (1992) A comparative study of the population dynamics, life history characteristics and physiological ecology of Callinectes sapidus and Callinectes simulis in estuarine environments of the Northern Gulf of Mexico. PhD dissertation, University of Alabama at Birmingham

Hsueh PW, McClintock JB, Hopkins TS (1993) Population dynamics and life history characteristics of the blue crabs Callinectes similis and C. sapidus in bay environments of the northern Gulf of Mexico. PSZN I: Mar Ecol 14:239-257

Johnson DF (1985) The distribution of brachyuran crustacean megalopae in the waters of the York River, lower Chesapeake Bay and adjacent shelf: implication for recruitment. Estuar coast Shelf Sci 20:693-705

Johnson LE (1989) Settling barnacle larvae avoid substrata previously occupied by a mobile predator. J exp mar Biol Ecol 128:87-103

Jones GP (1990) The importance of recruitment to the dynamics of a coral reef fish population. Ecology 71:1691-1698

Kalber FA Jr (1970) Osmoregulation in decapod larvae as a consideration in culture techniques. Helgoländer wiss Meeresunters 20:697-706

King BD IIl (1971) Study of migratory patterns of fish and shellfish through a natural pass. Tex Parks Wildl Tech Serv $9: 1-54$

Linden PF, Simpson JE (1988) Gravity-driven flows in a turbulent fluid. J Fluid Mechanics 172:481-497

Lupcius RN, Olmi EJ III, van Montfrans J (1990) Planktonic availability, molt stage and settlement of blue crab postlarvae. Mar Ecol Prog Ser 58:235-242

Little KT. Eplfanio CE (1991) Mechanism for the reinvasion of the estuary by two species of brachyuran megalopae. Mar Ecol Prog Ser 68:235-242

Luckenbach MW, Orth RJ (1992) Swimming velocities and behavior of blue crab (Callinectes sapidus Rathbun) megalopae in still and flowing water. Estuaries 15: 186-192

Lysinger WR (1982) An analysis of the hydrographic conditions found in the main pass of Mobile Bay, Alabama. Master's thesis, University of Alabama, Tuscaloosa

McClintock JB, Marion KR, Dindo J, Hsueh PW, Angus RA (1993) Population studies of blue crabs in soft-bottom, unvegetated habitats of a subestuary in the northern Gulf of Mexico. J Crust Biol 13:551-563

McConaugha JR (1988) Export and reinvasion of larvae as regulators of estuarine decapod populations. Am Fish Soc Symp 3:90-103

Menge BA (1991) Relative importance of recruitment and other causes of variation in rocky intertidal community structure. J exp mar Biol Ecol 146:69-100

Mense DJ, Wenner EL (1989) Distribution and abundance of early life history stages of the blue crab. Callinectes sapidus, in tidal marsh creeks near Charleston, SC. Estuaries $12: 157-168$

Metcalf KS, Lipcius RN (1992) Relationship of habitat and spatial scale with physiological state and settlement of blue crab postlarvae in Chesapeake Bay. Mar Ecol Prog Ser 82:143-150

Metcalf KS, van Montfrans J, Lipcius RN, Orth RJ (1995) Settlement indices for blue crab megalopae in the York River,
Virginia: temporal relationships and statistical efficiency. Bull mar Sci 57 (in press)

Mokady O, Bonar DB, Arazi G, Loya Y (1991) Coral host specificity in settlement and metamorphosis of the date mussel Lithophaga lessepsiana (Vaillant, 1865). J exp mar Biol Ecol 146:205-216

Morgan SG (1995) Life and death in the plankton: larval mortality and adaptation. In: McEdwards L (ed) Larval ecology of marine invertebrates. CRC, Boca Raton, FL, p 279-321

Morisawa M (1968) Streams: their dynamics and morphology. McGraw-Hill, New York

Nixon SW (1980) Between coastal marshes and coastal waters - a review of twenty years of speculation and research on the role of salt marshes in estuarine productivity and water chemistry. In: Hamilton P, McDonald KB (eds) Estuarine and wetland processes. Plenum, New York, p 437-525

Nunes Vaz RA, Lennon GW, De Silva Samarasinghe JR (1989) The negative role of turbulence in estuarine mass transport. Estuar coast Shelf Sci 28:361-377

Olmi EJ III (1994) Vertical migration of blue crab Callinectes sapidus megalopae: implications for transport in estuaries. Mar Ecol Prog Ser 113:39-54

Olmi EJ III (1995) Ingress of blue crab megalopae in the York River, Virginia, 1987-1989. Bull mar Sci 57:753-780

Olmi EJ III, van Montfrans J, Lipcius RN, Orth RJ, Sadler P (1990) Variation in planktonic availability and settlement of blue crab megalopae in the York River, Virginia. Bull mar Sci 46:230-243

Orth RJ, van Montfrans J (1987) Utilization of seagrass meadow and tidal marsh creek by blue crabs Callinectes sapidus. I. Seasonal and annual variation in abundance with emphasis on post-settlement juveniles. Mar Ecol Prog Ser 41:283-294

Perry HM (1975) The blue crab fishery in Mississippi. Gulf Res Rep 5:39-57

Pineda J (1991) Predictable upwelling and the shoreward transport of planktonic larvae by internal tidal bores. Science 253:548-551

Provenzano AJ Jr, McConaugha $J R$, Philips KB, Johnson DF, Clark $J$ (1983) Vertical distribution of first stage larvae of the blue crab, Callinectes sapidus, at the mouth of the Chesapeake Bay. Estuar coast Shelf Sci 16:489-499

Rabalais NN, Burditt FR Jr, Coen LD, Cole BE, Eleuterius C, Heck KL Jr, McTigue TA, Morgan SG, Perry HM, Truesdale FM, Zimmer-Faust RK, Zimmerman RJ (1995) Settlement of Callinectes sapidus megalopae on artificial collectors in four Gulf of Mexico estuaries. Bull mar Sci 57 . $855-876$

Rumrill SS (1990) Natural mortality of marine invertebrate larvae. Ophelia 32:163-198

Schroeder WW (1978) Riverine influence on estuaries: a case study. In: Wiley ML (ed) Estuarine interactions. Academic, New York, p 347-364

Schroeder WW, Lysinger WR (1979) Hydrography and circulation of Mobile Bay. In: Loyacano HA, Smith JP (eds) Symposium on the Natural Resources of the Mobile Bay estuary. US Army Corps of Engrneers, Mobile district, Mobile, AL, p 75-98

Schroeder WW, Wiseman WJ Jr (1986) Low-frequency shelfestuarine exchange processes in Mobile Bay and other estuarine systems on the northern Gulf of Mexico. In Wolfe DA (ed) Estuarine variability. Academic, New York, p 355-367

Shanks AL (1988) Further support for the hypothesis that internal waves can cause shoreward transport of larval invertebrates and fish. Fish Bull US 86:703-714 
Sharples J, Simpson JH (1993) Periodic frontogenesis in a region of freshwater influence. Estuaries 16:74-82

Smith NP (1.977) Meteorological and tidal exchanges between Corpus Christi Bay, Texas, and the northwestern Gulf of Mexico. Estuar coast mar Sci 5:511-520

Smyth PO (1980) Callinectes (Decapoda: Portunidae) larvae in the Middle Atlantic Bight, 1975-77 Fish Bull 78: $251-265$

Stout JP, Lelong MG (1981) Wetland habitats of the Alabama coastal area. Part II. An inventory of wetland habitats south of the Battleship Parkway. Tech Pub CAB-81-01, Alabama Coastal Area Board, Montgomery

Stuck KC, Perry HM (1982) Morphological characteristics of blue crab larvae, Callinectes sapidus Rathbun, from the northern Gulf of Mexico. Gulf States Mar Fish Comm Completion Rep 000-011, Ocean Springs, MS

Stumpf RP, Gelfenbaum G, Pennock JR (1993) Wind and tidal forcing of a buoyant plume, Mobile Bay, Alabama. Cont Shelf Res 13:1281-1,301

Sutherland JP (1990) Recruitment regulates demographic variation in a tropical intertidal barnacle. Ecology 71 955-972

Swenson EM, Chuang WS (1983) Tidal and subtidal water volume exchange in an estuarine system. Estuar coast Shelf Sci 16:229-240

Thayer GW, Stuart HH (1974) The bay scallop makes its bed of seagrass. Mar Fish Rev 36:27-30

Thomas J, Zimmerman F, Mineilo T (1990) A comparison of seagrass, salt marsh and bare sand as nursery habitats for juvenile Callinectes sapidus. Bull mar Sci 46:115-125

Thorson G (1950) Reproductive and larval ecology of marine bottom invertebrates. Biol Rev 25:1-45

Truesdale FM, Andryszak BL (1983) Occurrence and distribution of reptant decapod crustacean larvae in neritic Louisiana waters: July 1976. Contr mar Sci 26:37-53

Turner RE (1977) Intertidal vegetation and commercial yields of penaeid shrimp. Trans Am Fish Soc 106:411-416

This article was presented by J. Pawlik, Wilmington, North Carolina, USA
Underwood AJ, Fairweather PG (1989) Supply-side ecology and benthic marine assemblages. Trends Ecol Evol 4:16-20 van Montfrans J, Epifanio CE, Knott DM, Lipcius RN, Mense DJ, Metcalf KS, Olmi EJ III, Orth RJ, Posey MH, Wenner EL, West TL (1995) Settlement of blue crab megalopae in western North Atlantic estuaries. Bull mar Sci 57:834-854 van Montfrans J, Peery CA, Orth RJ (1990) Daily, monthly and annual settlement patterns by Callnectes sapidus and Neopanope sayi megalopae on artificial collectors deployed in the York River, Virginia. Bull mar Sci 46: $214-229$

Ward GH Jr (1980) Hydrography and circulation processes of Gulf estuaries. In: Hamilton P, MacDonald KB (eds) Estuarine and wetland processes with emphasis on modeling Plenum, New York, p 183-215

Williams AB (1971) A ten year study of meroplankton in North Carolina estuaries: annual occurrence of some brachyuran developmental stages. Chesapeake Sci 1.2:53-61

Williams AB (1984) Shrimps, lobsters and crabs of the Atlantic coast. Smithsonian Institution Press, Washington, DC

Williams AH, Coen D. Stoelting MS (1990) Seasonal abundance, distribution and habitat selection of juvenile Callinectes sapidus (Rathbun) in the northern Gulf of Mexico. $J$ exp mar Biol Ecol 137:165-183

Wilson KA, Heck KL Jr, Able KW (1.987) Juvenile blue crab (Callinectes sapidus) survival: an evaluation of eelgrass (Zostera marina) as refuge. Fish Bull US 85:53-58

Wolcull DL, De V'rles MC (1994) Offshore megalopae of Callinectes sapidus: depth of collection, molt stage and response to estuarine cues. Mar Ecol Prog Ser 109:157-163

Young CM (1989) Selection of predator-free settlement sites by larval ascidians. Ophelia 30:131-140

Young CM (1990) Larval ecology of marine invertebrates: a sesquicentennial history. Ophelia 32:1-48

Zimmerman RJ, Minello TJ (1984) Densities of Penaeus aztecus, Penaeus setiferus and other natant macrofauna in a Texas salt marsh. Estuaries 7:421-433

Manuscript first received: April 10, 1995

Revised version accepted: September 7, 1995 